\title{
Assimilation and contrast effects in suboptimal affective priming paradigm
}

\section{Dorota Kobylińska * and Dorota Karwowska \\ Department of Personality Psychology, Faculty of Psychology, University of Warsaw, Warsaw, Poland \\ ${ }^{*}$ Correspondence: dorotak@psych.uw.edu.pl}

Edited and reviewed by:

Petko Kusev, Kingston University London, UK

Keywords: suboptimal affective priming, assimilation effect, contrast effect, emotion regulation

\section{SUBOPTIMAL AFFECTIVE PRIMING PARADIGM}

Contemporary psychology does not question the existence of psychological processes that operate outside human conscious awareness, such as implicit stereotypes (Greenwald and Banaji, 1995; Nosek et al., 2009), implicit attitudes (Greenwald and Banaji, 1995), automatically activated goals or norms (Bargh, 1997; Bargh and Chartrand, 2000; Bargh et al., 2001; Dijksterhuis et al., 2005), and implicit primary affect (Zajonc, 1980, 2004; Murphy and Zajonc, 1993; Murphy et al., 1995; Jarymowicz and Kobylińska, 2005; Winkielman et al., 2005; Kobylińska and Karwowska, 2007). Most data showing implicit affective stimuli influence on evaluative judgments, come from experiments conducted in an affective priming paradigm. The paradigm was introduced by Murphy and Zajonc (1993) who presented evidence for the existence of unconscious primary affect (Zajonc, 1980) and its influence on cognition. In their original experiments they presented neutral target stimuli (for example Chinese ideographs), which were preceded by either 1-s or 4-ms exposures of photographs of faces expressing either positive or negative emotions. The results showed that suboptimal $(4 \mathrm{~ms})$ affective primes induced affect that influenced evaluations of the neutral targets. Ideographs primed by negative facial expressions were judged more negatively than those primed by positive ones. Interestingly, neither the facial expression nor even the presence of any image was accessible to the participants' awareness. In contrast to suboptimal affective primes, both optimal affective primes (exposed for $1 \mathrm{~s}$ ) and affectively neutral suboptimal primes (e.g., geometric figures of different shapes) failed to influence the participants' judgments about targets.

This was the first effect observed in affective priming research. However, it turned out in later studies that the reverse effect is also possible (Glaser and Banaji, 1999; Ohme et al., 1999). The first effect, when judgments about neutral stimuli are consistent with the valance affective primes, is referred to as the assimilation effect. The reverse effect, when targets primed negatively are evaluated more positively than those primed positively (thus inconsistently with priming valance), is called the contrast effect. It turned out that which of the two effects is obtained is not a matter of chance but is related to important psychological and neurobiological processes occurring at the time when affect is elicited.

Both effects are quite simple and both proof that judgments may be influenced by stimuli presented outside conscious awareness. Accordingly, in this opinion article, we will explore the psychological mechanism underlying the effects of assimilation and contrast.

\section{EVIDENCE FOR OBTAINING ASSIMILATION OR CONTRAST EFFECTS IN PRIMING RESEARCH}

Traditionally in research applying explicit semantic priming, the contrast effect was explained as coming from the fact that participants were aware of priming manipulation or of the influence of priming on the target task (Lombardi et al., 1987; Newman and Uleman, 1990; Strack et al., 1993) or from engaging additional cognitive resources and effort to resist the primary reaction induced by priming. This primary reaction is rather based on assimilation to priming (Martin et al.,
1990), while the contrast effects is usually described as resulting from more complex information processing that requires, at least, elementary processes of comparisons (Lombardi et al., 1987; Martin et al., 1990; Ric and Niedenthal, 2007). However, when contrast effect is obtained in suboptimal affective priming procedure, it cannot be explained by participants' awareness.

Glaser and Banaji (1999) found assimilation and contrast effects in their experiment on implicit semantic priming. They showed that priming words that were salient in their affective meaning produced contrast effect, whereas affectively mild words produced assimilation effect. Such results confirmed the earlier results of Herr et al. (1983). Similar pattern was later obtained in advertising studies (Vianello et al., 2009).

Ohme et al. (1999) obtained contrast effect in three experiments in suboptimal affective priming paradigm in which they used Chinese hexagrams (instead of ideographs) as target stimuli. This change required different instruction for participants. Instead of evaluating the attractiveness of targets, participants had to decide (using 5-point Likert scale) if the hexagrams represent chaos and conflict or order and harmony. Those concepts are related to negativity and positivity: chaos and conflict is associated with decay whereas order and harmony with tranquillity and peace. In all three experiments contrast effect was registered: hexagrams primed negatively were evaluated higher (more positively) then those primed positively and not primed affectively. In discussion of their results Ohme and others argued that the contrast effects were obtained because of (1) more abstract instruction, potentially 
engaging information processing related to the functions of the left cerebral hemisphere and (2) using hexagrams that seem to activate more analytical information processing then ideographs.

Further evidence comes from experiments by Kobylińska (2001, 2007). She based her hypotheses on the following reasoning. Some researchers indicated that in conditions of implicit affective priming the contrast effect, in comparison to the assimilation effect, results from slightly larger contribution of cognitive processes in the evaluation process (Dijksterhuis et al., 1998; Kolańczyk et al., 2001, 2007; Kolańczyk and Pawłowska-Fusiara, 2002; Mussweiler and Damisch, 2008). Contrast seems to require more detailed processing of affective information by neural system, since it appears not as a direct consequence of priming but only after employing some other parallel competing process. According to neurophysiological findings (Libet, 1996), the stronger a stimulus, the more complex neural structures participate in its processing and the more complex reactions are produced. By stronger stimulation we may understand more salient affective stimuli or just stimuli lasting longer. Zajonc (2004) claims that when the exposure of affective stimulus is lengthened, subject gains access to more information about the stimulus.

In several experiments Kobylińska (and later Kobylińska and Karwowska) used different exposure durations of affective primes as operationalization of salience of affective stimulation. Confirming the predictions, the results showed assimilation effect when the exposure duration of primes was shorter- $4 \mathrm{~ms}$ - and the contrast effect, with the longer duration of $16 \mathrm{~ms}$ (Kobylińska, 2001, 2007; Kobylińska and Karwowska, 2007). The results indicate that influence of the nonconscious primary affect may be bidirectional (assimilation or contrast effects) and the conscious perception of the affective stimulus (or its influence) is not necessary for that. The lengthening of the exposure duration of affective stimuli from 4 to $16 \mathrm{~ms}$ does not make the stimulus accessible to consciousness. However, the influence of affect elicited by stimuli exposed for 4 or $16 \mathrm{~ms}$ was different, in fact it was just the reverse.

\section{CONTRAST EFFECT AS A RESULT OF IMPLICIT EMOTION REGULATION}

According to Glaser and Banaji (1999) the contrast effects obtained in nonconscious affective priming research may result from spontaneous application of autocorrection process that corrects the primary, direct assimilative effects of affective primes. It can be understood as a very basic process of automatic control (Kolańczyk et al., 2001, 2007) aimed at reducing the nonconscious influence of affective primes biasing evaluation of neutral objects. This process occurs without participants' awareness, and that is why instead of resulting in neutral evaluations it results in certain overcompensation. Glaser and Kihlstrom (2005) describe many studies on different implicit phenomena (for example attitudes or stereotypes) in which contrast effects were obtained. They suggest that contrast may result from automatically activated and operating nonconsciously accuracy motivation. Those explanations suggest that nonconscious processes are not entirely uncontrolled (see Glaser, 2003).

Coming back to the effects of suboptimal affective priming we argue that the assimilation effect can be modified under certain circumstances such as more salient (lasting longer) affective stimulation. Thus, the nature of nonconscious affective priming may be more complex that was originally assumed and may be mediated by automatic processes of implicit emotion regulation (Bargh and Williams, 2007). This way of thinking is supported by recent studies of Koole and colleagues (Koole and Jostmann, 2004; Koole and Rothermund, 2011a,b). They discuss the role of implicit emotion regulation and refer to it as counter-regulation. This line of studies shows that incongruency effect (that is defined in line with contrast effect definition presented above) appears when induced emotions are quite strong (affectively hot context) and there is a need to employ affect regulation).

Summing up, even when affect is elicited nonconsciously, some processes of (implicit) emotion regulation may appear automatically and modify the influence of affect on subsequent processes, as when we observe the contrast effect. This is one more argument for the substantial role of implicit processes in human life.

\section{ACKNOWLEDGMENT}

Studies described in the paper were financed from BST 2011 number 1615 and BST 144509 (Faculty of Psychology, University of Warsaw).

\section{REFERENCES}

Bargh, J. A. (1997). "The automaticity of everyday life," in The Automaticity of Everyday Life: Advances in Social Cognition, Vol. 10, ed. R. S. Wyer Jr. (Mahwah, NJ: Erlbaum), 1-61.

Bargh, J. A., and Chartrand, T. L. (2000). "Studying the mind in the middle: a practical guide to priming \& automaticity research," in Handbook of Research Methods in Social and Personality Psychology, eds H. T. Reis and C. M. Judd (New York, NY: Cambridge University Press), 17-39.

Bargh, J. A., Gollwitzer, P. M., Lee-Chai, A., Barndollar, K., and Trotschel, R. (2001). The automated will: nonconscious activation and pursuit of behavioral goals. J. Pers. Soc. Psychol. 81, 1014-1027. doi: 10.1037/0022-3514.81.6.1014

Bargh, J. A., and Williams, L. E. (2007). "Nonconscious regulation of emotion," in Handbook of Emotion Regulation, ed J. Gross (New York, NY: The Guilford Press), 429-445.

Dijksterhuis, A., Henk, A., and Smith, P. (2005). "The power of the subliminal: on the subliminal persuasion and other potential applications," in The New Unconscious, ed R. R. Hassin, J. S. Uleman, and J. A. Bargh (New York, NY: Oxford University Press), 77-106.

Dijksterhuis, A., Spears, R., Postmes, T., Stapel, D. A., and van Knippenberg, A. (1998). Seeing one thing and doing another: contrast effects in automatic behaviour. J. Pers. Soc. Psychol. 75, 862-871. doi: 10.1037/0022-3514.75.4.862

Glaser, J. (2003). "Reverse priming: implications for the (un)conditionality of automatic evaluation," in The Psychology of Evaluation, eds J. Musch and K. C. Klauer (London: Erlbaum), 87-108.

Glaser, J., and Banaji, M. R. (1999). When fair is foul and foul is fair: reverse priming in automatic evaluation. J. Pers. Soc. Psychol. 77, 669-686. doi: 10.1037/0022-3514.77.4.669

Glaser, J., and Kihlstrom, J. (2005). "Compensatory automacity: unconscious volition is not an oxymoron," in The New Unconscious, eds R. Hassin, J. Uleman, and J. A. Bargh (New York, NY: Oxford University Press). 171-195.

Greenwald, A. G., and Banaji, M. R. (1995). Implicit social cognition: attitudes, self-esteem and stereotypes. Psychol. Rev. 102, 4-27. doi: 10.1037/0033295X.102.1.4

Herr, P. M., Sherman, S. J., and Fazio, R. H. (1983). On the consequences of priming: assimilation and contrast effects. J. Exp. Soc. Psychol. 19, 323-340. doi: 10.1016/0022-1031(83)90026-4

Jarymowicz, M., and Kobylińska, D. (2005). Z badań nad wpływem utajonego afektu na formułowane sạdy w warunkach uprzedniego pobudzania do refleksyjności. Studia Psychologiczne. 43, 25-40.

Kobylińska, D. (2001). "Czas ekspozycji afektywnych bodźców poprzedzających a efekt asymilacji lub kontrastu," in Pomiędzy afektem a intelektem: doniesienia empiryczne, ed M. Jarymowicz (Warszawa: Wydawnictwo Instytutu Psychologii PAN), 73-82. 
Kobylińska, D. (2007). Automatyczna Kontrola Nieświadomych Emocji [Automatic Control of Unconscious Emotions - in Polish]. Warszawa: Wydawnictwa UW.

Kobylińska, D., and Karwowska, D. (2007). The influence of lateral implicit visual affective stimuli on the evaluation of neutral stimuli in humans. Acta Neurobiol. Exp. 67, 93-102.

Kolańczyk, A. (2001). The role of affect in preconscious and conscious processing. Pol. Psychol. Bull. 32, 27-37.

Kolańczyk, A. (2007). "Asymilacyjne i kontrastowe oceny wzglêdem nieuœwiadomionego afektu-próba interpretacji," in Tajemnice Nieuxwiadomionego Afektu. Paradygmat Podprogowego Poprzedzania, ed R. Ohme (Gdańsk: GWP), 101-114.

Kolańczyk, A., and Pawłowska-Fusiara, M. (2002). Automatic correction or controlled processing of affective priming. Pol. Psychol. Bull. 33, 35-44.

Koole, S. L., and Jostmann, N. B. (2004). Getting grip on your feelings: effects of action orientation and external demands on intuitive affect regulation. J. Pers. Soc. Psychol. 87, 974-990. doi: 10.1037/0022-3514.87.6.974

Koole, S. L., and Rothermund, K. (2011a). I feel better but I don't know why: the psychology of implicit emotion regulation. Cogn. Emot. 25, 389-399. doi: 10.1080/02699931.2010.550505

Koole, S. L., and Rothermund, K. (2011b). The psychology of emotion regulation. Cogn. Emot. 25, 389-573. doi: 10.1080/02699931.2010.550505

Libet, B. (1996). "Neural processes in the production of conscious experience," in The Science of Consciousness. Psychological, Neuropsychological and Clinical Reviews, ed M. Velmans (London; New York: Routledge), 96-117. doi: 10.4324/ 9780203360019_chapter_5

Lombardi, W. J., Higgins, E. T., and Bargh, J. A. (1987). The role of consciousness in priming effects: assimilation versus contrast as a function of awareness of priming task. Pers. Soc. Psychol. Bull. 13, 411-429. doi: 10.1177/01461672871 33009
Martin, L. L., Seta, J. J., and Crelia, R. A. (1990). Assimilation and contrast as a function of people's willingness and ability to expand effort in forming an impression. J. Pers. Soc. Psychol. 59, 27-37. doi: 10.1037/0022-3514.59.1.27

Murphy, S. T., Monahan, J. L., and Zajonc, R. B. (1995) Additivity of nonconscious affect: combined effects of priming and exposure. J. Pers. Soc. Psychol. 69, 589-602. doi: 10.1037/00223514.69.4.589

Murphy, S. T., and Zajonc, R. B. (1993). Affect, cognition and awareness: affective priming with optimal and suboptimal stimulus exposures. J. Pers. Soc. Psychol. 64, 723-739. doi: 10.1037/00223514.64.5.723

Mussweiler, T., and Damisch, L. (2008). Going back to Donald: how comparisons shape judgmental priming effects. J. Pers. Soc. Psychol. 95, 1295-1315. doi: 10.1037/a0013261

Newman, L. S., and Uleman, J. S. (1990). Assimilation and contrast effects in spontaneous trait inference. Pers. Soc. Psychol. Bull. 16, 224-240. doi: 10.1177/0146167290162004

Nosek, B. A., Smyth, F. L., Sriram, N., Lindner, N. M., Devos, T., Ayala, A., et al. (2009). National differences in gender-science stereotypes predict national sex differences in science and math achievement. Proc. Natl. Acad. Sci. U.S.A. 106, 10593-10597. doi: 10.1073/pnas.0809921106

Ohme, R. K., Pochwatko, G., and Błaszczak, W. (1999). "Paradygmat afektywnego poprzedzania: w poszukiwaniu nowej procedury badawczej," in Utajony wplyw Afektu na Procesy Poznawcze: Wybrane Metody Badañ. Studia Psychologiczne Numer Specjalny, Vol. 37, eds R. K. Ohme and M Jarymowicz, 7-28.

Ric, F., and Niedenthal, P. M. (2007). "Assimilation and contrast effects of affect on judgment," in Assimilation and Contrast in Social Psychology, eds D. A. Stapel and J. Suls (New York, NY: Psychology Press), 99-115.

Strack, F., Schwarz, N., Bless, H., and Kübler, A. (1993). Awareness of the influence as a determinant of assimilation versus contrast. Eur. J.
Soc. Psychol. 23, 53-62. doi: 10.1002/ejsp.2420 230105

Vianello, M., Galliani, E. M., and Da Carlo, N. A. (2009). Implicit contrast and explicit assimilation effects following subtle and blatant advertising. Test. Psychometrics Methodol. Appl. Psychol. 16, 129-139.

Winkielman, P., Berridge, K. C., and Wilbarger, J. L. (2005). Unconscious affective reaction to masked happy versus angry faces influence consumption behavior and judgments of value. Pers. Soc. Psychol. Bull. 31, 121-135. doi: 10.1177/0146167204 271309

Zajonc, R. B. (1980). Feeling and thinking: preferences need no inferences. Am. Psychol. 39, 117-123. doi: 10.1037/0003-066X.39.2.117

Zajonc, R. B. (2004). "An unmadiated phenomenon," in Feelings and Emotions, eds A. Manstead, N. Frijda, and A. Fisher (Cambridge Univeristy Press). 194-203. doi: 10.1017/CBO9780511806582.012

Conflict of Interest Statement: The authors declare that the research was conducted in the absence of any commercial or financial relationships that could be construed as a potential conflict of interest.

Received: 07 April 2014; accepted: 07 May 2014; published online: 26 May 2014.

Citation: Kobylinska D and Karwowska D (2014) Assimilation and contrast effects in suboptimal affective priming paradigm. Front. Psychol. 5:498. doi: 10.3389/ fpsyg.2014.00498

This article was submitted to Cognition, a section of the journal Frontiers in Psychology.

Copyright (C) 2014 Kobylinska and Karwowska. This is an open-access article distributed under the terms of the Creative Commons Attribution License (CC BY). The use, distribution or reproduction in other forums is permitted, provided the original author(s) or licensor are credited and that the original publication in this journal is cited, in accordance with accepted academic practice. No use, distribution or reproduction is permitted which does not comply with these terms. 